\title{
Bazı Ekmeklik Buğday Çeșitlerinde Verim Stabilitesinin Biplot ve AMMI Analiz Yöntemleri ile Değerlendirilmesi
}

\section{Erol ORAL"'(i), Enver KENDAL'(D), Yusuf DOĞAN'}

\author{
${ }^{\prime}$ Mardin-Artuklu Üniversitesi Kızıltepe Meslek Yüksek Okulu, Mardin
}

Öz: Bu çalıșmada, bazı ekmeklik buğday çeșitlerinin verim performansı, stabilitesi ve çeșit $\mathrm{x}$ çevre interaksiyonları incelenmiștir. Denemeler tesadüf blokları deneme desenine göre dört tekrarlamalı ve sulu șartlarda yürütülmüștür. Tane verimi, ana etkiler ve çarpımsal interaksiyonlar (AMMI) analizi ile değerlendirilmiștir. Kareler ortalaması sırasıyla; \%83.34' ü çevreden, \% 10.35'i çeșit x çevre interaksiyonundan ve \%6.29'ü ise çeșitten kaynaklandığı saptanmıștır. Tane verimi en fazla çevre șartlarından etkilenmiș faktörler \%0.0I 'e göre önemli olduğu tespit edilmiștir. PCA I ve PCA 2 eksenlerinin çeșit çevre interaksiyonundaki etkisi sırasıyla \%62.35 ve \%37.65 olduğu saptanmıștır. AMMI analizi sonuçlarına göre Nurkent çeșidi negatif $b$ değerine sahip olsa da hem stabil hem de en yüksek verimli, Bitacora çeșidinin (yurt dıșı tescilli) ise verim ortalamasının üzerinde bir verime sahip olup stabilite çizgisinden oldukça uzak olduğu tespit edilmiștir. Ayrıca çalıșmanın yürütüldüğü Șanlıurfa lokasyonunun yüksek verim $(740.8 \mathrm{~kg} / \mathrm{da})$ Diyarbakır lokasyonunun düșük verim $(54 \mathrm{l} . \mathrm{l} \mathrm{kg} / \mathrm{da})$ potansiyeli çevre șartlarına sahip olduğu anlașılmıștır. Araștırma sonuçlarına göre, mevcut iki çeșitten daha yüksek diğer üç çeșitten daha düșük verime sahip Bitacora çeșidi, Șanlıurfa lokasyonunda ilk sırada tercih edilmesi gereken çeșit olduğu tespit edilmiștir. Ekmeklik buğday açısından tane verimi kadar önemli olan kalite kriterleri açısından da iyi sonuçlara sahip olduğu takdirde, bu aday çeșidin araștirmanin yürütüldüğü bölgelerde yetiștiriciliğinin tavsiye edilebileceği sonucuna varılmıștır.

Anahtar Kelimeler: çeșit adayı, stabilite, verim, AMMI, biplot

\section{Some Bread Wheat Varieties Yield Stability Evaluation with Biplot and AMMI Analysis Methods}

\begin{abstract}
In this study, the yield performance, stability and cultivars environmental interactions several of some bread wheat cultivars were evaluated in two different environmental conditions. The trials were implemented in respect to a integrate arrangement complex style with four replications in irrigation conditions. The AMMI (Additive main effects and multiplicative interaction) analysis was made to estimate grain yield and understand $G \times E$ interaction patterns. The major contributions to treatment sum of squares were environments (83.34\%), GE (I0.35\%), and cultivars (6.29\%) respectively. The effects of PCAI and PCA2 were found to be $62.35 \%$ and $437.65 \%$, respectively, in various environmental interactions. According to AMMI analysis results and stability values, Nurkent variety was found to be both highly efficient and stable, Bitacora variety (abroad registered) was found to be efficiency more than mean yield, but unstable. In addition, it was understood that Șanliurfa location environmental conditions where the study was carried out have high yield potential (7408 kg/ha), while Diyarbakır with low yield potential (54II kg/ha). According to the results of the research, it is understood that the Bitacora variety has higher yield potential than the two existing varieties, but have lower than three other varieties, but it is should be prefered firstly in Șanliurfa location. If it has good results in terms of quality criteria which is as important as yielding wheat grain from bread wheat, this candidate can be recommended to cultivate for research area.
\end{abstract}

Keywords: candidate, stability, yield, AMMI, biplot

\section{GiRiș}

Buğday, dünyanın dört bir tarafında ana beslenme kaynağı olarak kullanılması ve yüksek adaptasyon yeteneğine sahip olması ve nedeni ile hala araștırılması gereken önemli bir tarla bitkisidir (Kendal, 20l3). Temel olarak ekmeklik (Triticum aestium L.) ve makarnalık (Triticum durum L.) buğday olmak üzere iki gruba ayrılmaktadır. Ekmeklik buğday; hem adaptasyon yeteneğinin yüksek olması hem de temel besin kaynağı olarak ekmek yapımından kullanılması nedeni ile dünya genelinde daha fazla araștırma konusu olmuș buna bağlı olarak da daha geniș bir alana yayılmıștır. Dünyada tüketim amaçlı olarak kullanılan buğdayların yaklașık \%95'ini ekmeklik buğdaylar oluștururken, geri kalan \%5'lik kısmını ise makarnalık ve spelta buğdaylarıdır (Kılıç ve ark., 20l4). Son yıllarda buğday ekim alanlarının Güneydoğu Anadolu Bölgemizde ekmeklik lehine artması, üreticilerin pazar değerini göz önüne alarak yeni çeșitlere yönelmesi sonucu çeșit sayısında bir artıștan söz etmek mümkündür (Kılıç ve ark., 2016). Özellikle üreticilerin özel taleplerinin yanı sıra bir birleri ile olan karșılıklı etkileșimleri verim dalgalanmalarını azaltacak șekilde doğru çeșitlerin önerilmesi ile mümkündür (Kılıç ve ark., 2005).

Islah programları genel olarak üretici, sanayici ve tüketici istekleri dikkate alınarak olușturulmaya çalıșılmaktadır. $\mathrm{Bu}$ amaçla tane verimi ve kaliteyi artırmaya esas yetiștirme teknikleri ve çeșit geliștirme programlarında çeșitli ıslah yöntemleri kullanılmakla birlikte seleksiyon önemli bir yer tutmaktadır. Nitekim uzun yıllar süren ve yorucu emek gerektiren çeșit ıslahında hedefe ulașma, üzerinde çalıșılan karakterlerin genetik mekanizmalarının bilinmesi ve buna bağlı olarak uygun genotiplerin seçimine bağlıdır (Kılıç ve ark., 20I2). Islah sürecinin uzun yıllar alması ve ülkemizdeki yazlık ekmeklik buğday çalıșmaları için geliștirilen çeșit sayısının az olması, ayrıca

Sorumlu Yazar: eroloral@artuklu.edu.tr Geliș Tarihi: 2 Ocak 2018

Kabul Tarihi: I Haziran 2018 
buğday üretici çiftçilerimizin yabancı çeșitlere yönelik așırı ilgileri ve tohum üretim firmalarının royalite hakkından kurtulmak için kısa yoldan kendi çeșitlerine sahip olma istekleri yurt dıșında tescil edilmiş çeșitlerin yurt içinde iki yıl denenmek suretiyle uygun sonuçlar elde edildiği takdirde tescil edilmelerine olanak sağlamaktadır (Kendal ve ark., 20I2). Ülkemiz dolayısıyla bölgemizin ekmeklik buğday açısından var olan üretim potansiyeli hem son zamanlarda ülkemizde tescil edilen verimli ve kaliteli çeșitlerin yaygınlaștırılması ile hem de yurtdıșında tescil edilmiș ancak bölgemizin șartlarına adapte olabilecek verimli ve özellikle kaliteli çeșitlerin ülkemizde tescil edilmesi ve yaygınlaștırılması ile artırılabilir.

Ekmeklik buğday, hem yağıșa dayalı șartlarda hem de sulu șartlarda yetiștirildiğinden dolayı genotip, çevre ve tahmin edilemeyen iklim koșullarında verimi değișmektedir. Bu nedenle bașka yerlerde tescil edilen veya ıslah çalıșmaları henüz devam eden çeșit adaylarının uygun ekolojilerde yetiștirilmesi için adaptasyon çalıșmaları yapılmaktadır. Bu anlamda uygun ekolojilere uygun çeșitlerin bulunması için yürütülen çalıșmalarda çeșit, çevre ve interaksiyon faktörlerinin her biri ayrı bir öneme sahiptir. Özellikle interaksiyon test edilen çevrelerde genotiplerin performansı hakkında bilgi sunmakta ve ıslah programlarında verim stabilitesinin ilerleyișinde önemli bir rol oynamaktadır (Kılıç ve ark., 2005). Tane verimi, bir çok genetik ve diğer faktörlerin etkisi altında fazla miktarda dalgalanma göstermektedir (Akter ve ark., 20I4). Bu nedenle, AMMI ve Biplot analiz modelleri hem iki yönlü veri yapısını hem de bir ıslahçının genotipik potansiyeli ve üzerinde çevresel etkilere ilișkin kesin tahmin etmeyi mümkün kılan ana etkiler ve çarpımsal interaksiyonları içeren kompleks bir model oldukları için kullanılması uygundur (Kılıç ve ark., 2012;

Çizelge I. Denemede kullanılan genotipler ve bazı özellikler

\begin{tabular}{llc}
\hline \multicolumn{1}{c}{ Çeșit/Hat adı } & Çeșitlerin ait olduğu kurumlar & Tescil Yılları \\
\hline Adana-99 & Çukurova Tarımsal Araștırma Enstitüsü & 1999 \\
Cemre & GAP Uluslar Arası Tarımsal Araștırma ve Eğitim Merkezi & 2008 \\
Nurkent & GAP Uluslar Arası Tarımsal Araștırma ve Eğitim Merkezi & 2000 \\
Pehlivan & Tırakya Tarımsal Araștırma Enstitüsü & 1998 \\
Sagittario & Tassako Tarım (İtalya tescilli) & $200 I$ \\
Bitacora (Yurt dıșı tescilli) & DNA Tarım ve Tohumculuk San. Ve Tic. Ltd.Ști. & Çeșit Adayı
\end{tabular}

Araștırmanın yürütüldüğü her iki çevre de yetiștirme sezonundaki aylık yağıș miktarı uzun yıllar aylık ortalama yağıș miktarı ile kıyaslandığında daha düzensiz yağıșın kaydedildiği Șekil I'de görülmektedir. Her iki çevrede de özellikle Kasım, Ocak yağıșlarının uzun yıllar ortalamasından daha yüksek ancak özellikle buğday bitkisinin en çok ihtiyaç duyduğu Șubat-Mayıs arasındaki gelișme döneminde daha düșük olduğu tespit edilmiștir. Yetiștirme sezonundaki ortalama aylık sıcaklık değerleri ise yağıș miktarlarının tersine bir durum sergilediği tespit
Kılıç ve ark., 2014; Kendal ve Tekdal, 2016; Sayar ve ark., 2016). AMMI ve Biplot analiz modelleri, çoklu çevreleri kullanan farklı araștırıcılar tarafından açık bir șekilde dile getirilmiș ve bu modeller çok değișkenli teknikler olup genotip ve çevre etkileșimlerinde ana etkiyi ve temel bileșen analizini karakterize ederek çeșit çevre interaksiyonu ile farklı genotiplerin çevreler üzerinde daha belirleyici görüntüler elde etmek, özel ve özel olmayan çevreleri belirlemek, çok özel çevreleri tanımlamak, farklı çevrelerde ileri kademedeki tescil adayı hatları test etmek, performanslarını ve stabilitesini tahmin etmek için çok uygun olduğu bir çok araștırıcı tarafından dile getirilmiștir (Aktaș, 2016; RadNouri ve ark., 2013; Kendal ve Șener 2015 Kendal ve ark., 2016b).

$\mathrm{Bu}$ çalıșmada, Biplot ve AMMI analiz modellerini kullanarak yurt dıș tescilli yazlık ekmeklik buğday çeșit adayının adaptasyon kabiliyetini ölçmek, diğer çeșitlerle rekabet gücünü araștırmak, tane verimi üzerinde genotip çevre interaksiyonunun etkisini görmek, büyük çevre gruplarını tanımlamak, her bir mega veya özel çevre için en iyi çeșidi belirlemek amaçlarımızı olușturmuștur.

\section{MATERYAL ve YÖNTEM}

Araștırmada materyal olarak, I adet yurt dıșı tescilli çeșit adayı ve 5 adet bölgede yaygın olarak ekimi yapılan çeșitler olmak üzere, toplam 6 tane ekmeklik buğday çeșidi kullanılmıștır (Çizelge I). Araștırmada kullanılan çeșitlerin adları, tescil edildikleri kurulușlar ve tescil edildikleri yılı gösteren bilgiler Çizelge I'de belirtilmiștir. Çalıșma, 20II_2012 yetiștirme sezonunda Diyarbakır (Merkez) ve Șanlıurfa /Ákçakale'de olmak üzere iki çevrede yürütülmüștür. Araștırmanın yürütüldüğü çevrelere ait yetiștirme sezonu ve uzun yıllar ortalaması yağıș miktarları Șekil I ve yetiștirme sezonu ve uzun yıllar aylık sıcaklık ortalamaları Șekil 2'de verilmiștir. edilmiștir (Șekil 2). Diyarbakır lokasyonunda sapa kalkma ve bașaklanmadan sonra iki sulama (yağmurlama) yapılmıștır. Araștırma süresince toplamda $200 \mathrm{ml}$ su verilmiștir. Șanlıurfa' da ise lokasyonunun daha sıcak ve kurak geçmesi nedeni ile çıkıș için bir defa, sapa kalkma, bașaklanmadan sonra ve süt olum döneminde olmak üzere toplam 4 sulama yapılmıș ve $400 \mathrm{ml}$ su verilmiștir. Denemeler tesadüf blokları deneme deseninde dört tekerrürlü olarak kurulmuștur. Deneme parselleri $6 \mathrm{~m}$ boyunda, I. $2 \mathrm{~m}$ genișliğinde her biri $20 \mathrm{~cm}$ aralıklı 6 sıra olacak șekilde $\left(1.2 \mathrm{~m} \times 6 \mathrm{~m}=7.2 \mathrm{~m}^{2}\right)$ deneme mibzer 


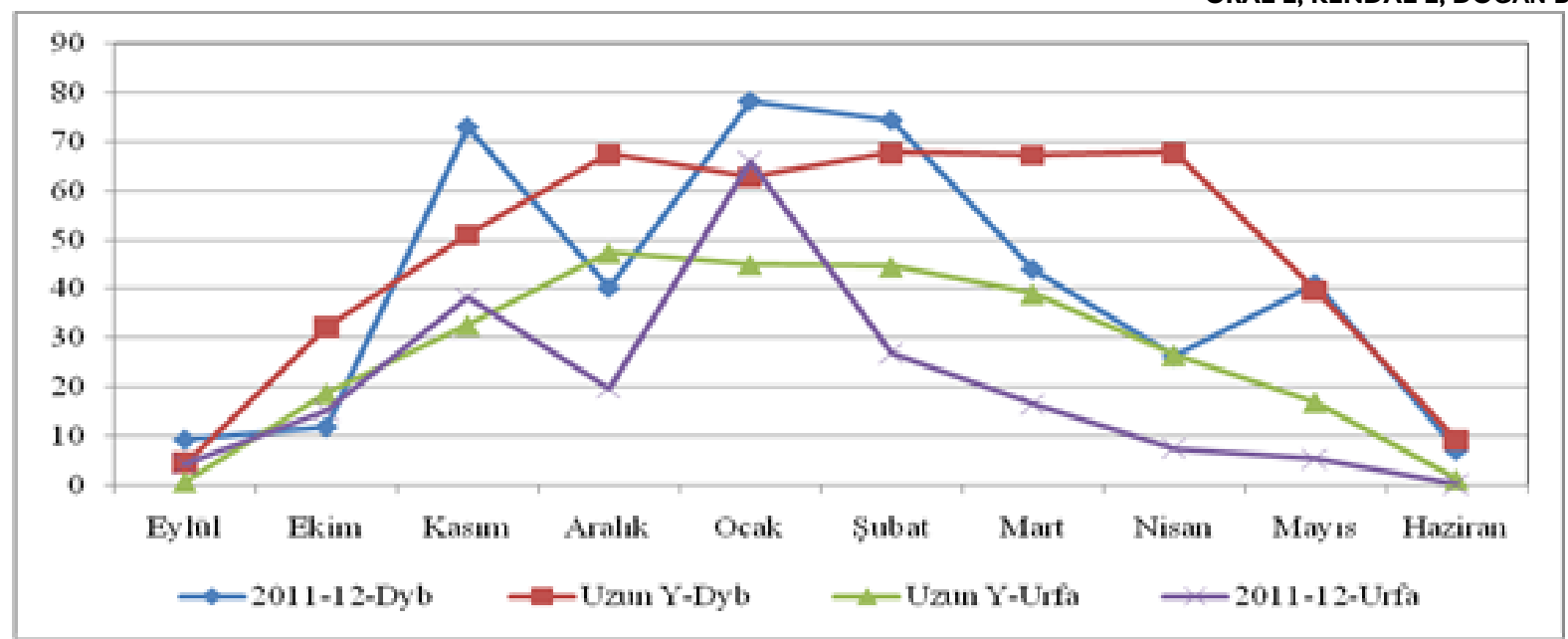

Șekil I. İllere ait yetiștirme sezonu ve uzun yıllar aylık ortalama yağıș miktarı $(\mathrm{mm})$ (www.meteor.gov.tr)

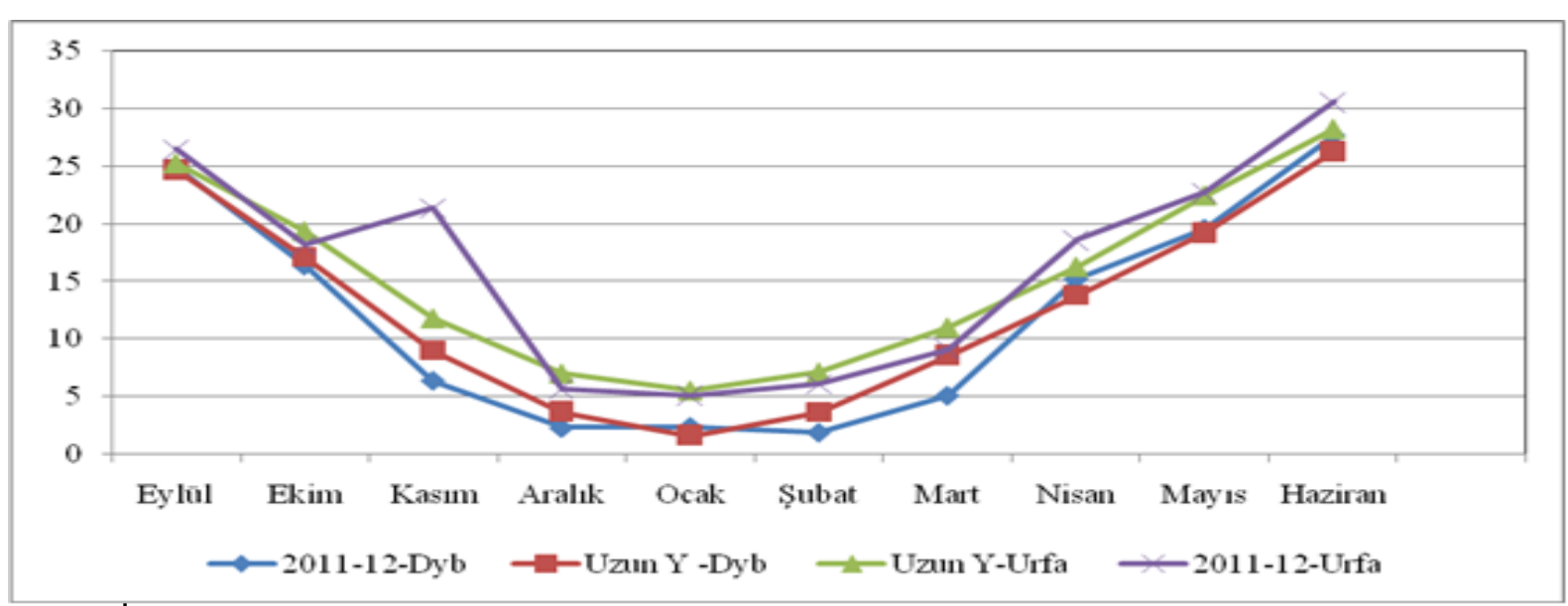

Șekil 2. İllere ait yetiștirme sezonu ve uzun yıllar aylık ortalama sıcaklık değerleri $\left({ }^{\circ} \mathrm{C}\right)$ (www.meteor.gov.tr) ile ekilmiștir. Her iki denemede de ekimle birlikte, dekara $6 \mathrm{~kg}$ saf $\mathrm{P}_{2} \mathrm{O}_{5}$ ve $6 \mathrm{~kg}$ saf N, Ayrica $6 \mathrm{~kg}$ saf N/da bahar gübresi olarak șubat ayının sonunda uygulanmıștır. Geniș yapraklı yabancı otlara karșı kimyasal mücadele yapılmıștır. Gelișme döneminde parsel bașlarından $0.5 \mathrm{~m}$ ve kenarlardan $0.4 \mathrm{~m}$ atılarak geriye kalan $(5 \mathrm{~m} \times 0.8 \mathrm{~m}=$ $\left.4 \mathrm{~m}^{2}\right)$ kısım parsel biçerdöveri ile hasat edilmiștir.

Güneydoğu Anadolu Bölgesinin yarı kurak ve çok sıcak iklim özellikleri, toprak yapısını da etkilemiștir. Bu topraklar düz ve düze yakın eğimlerde, derin veya orta derin, $A B C$ profilinde topraklardır. Bu profillerde organik madde ve fosfor kapsamları düșük olup su ile doyma yüzdeleri yüksek ve bazik özellik göstermektedir. Diyarbakır toprakları organik madde oranı, Șanlıurfa/ Akçakale toprakları ise tuz oranı bakımından daha yüksek değerlere sahiptir (Kendal, 20I3).

Araștırmadan elde edilen veriler JMP ve GenStatRelease I4.I (Copyright 20II, VSN International Ltd.) versiyonu kullanılarak değerlendirilmiștir (Gauch, 1988). Sonuçlar AMMI ve GGE biplot modelleri ile yorumlanmıștır.

\section{BULGULAR ve TARTIȘMA}

AMMI analiz metodu ile yapılan değerlendirmede farklı çevrelerde denenmiș olan 5 ekmeklik buğday çeșidi ve bir çeșit adayına (yurtdıșı tescilli) ait tane verimi bakımından çeșit, çevre ve çeșit çevre interaksiyonu istatistiksel olarak 0.01 düzeyinde önemli bulunmuștur. Ayrıca kareler ortalamasının sırasıyla \%83.34' ü çevreden, $\% 10.35$ 'i çeșit $x$ çevre interaksiyonundan ve \%6.29'ü ise çeșitten kaynaklandığı belirlenmiștir (Çizelge 2).

PCAI ve PCA2 eksenleri (Temel Bileșenler Ekseni) sırasıyla genotip çevre interaksiyonun \%62.35' ini ve \%37.65'ini olușturduğu ve \%0.0I'e göre önemli olduğu saptanmıștır (Çizelge 2 ve Șekil 4). Gauch ve Zobel (1996), AMMI modeli her iki temel bileșen ekseninin ya da daha fazlasının birlikte değerlendirebilen ve her birinin genotip çevre interaksiyonunu ne kadar etkilediğini oranlar ile ortaya koyan çok doğru bir model olduğunu bildirmektedir. Genotiplerin temel bileșen ekseni ortalama değerleri "0"sıfır değerine yaklaștıkça bu genotiplerin tüm çevrelerde stabil olduğunu göstermektedir. Çok yönlü analiz modeli genellikle AMMI I ve AMMI 2 olmak üzere iki farklı șekilde değerlendirilmektedir (Carbonell ve ark., 2004). 
Çizelge 2. Tane verimi üzerinden yapılan AMMI analizine ait varyans analiz sonuçları

\begin{tabular}{llllll}
\hline Varyasyon Kaynakları & $\begin{array}{l}\text { Serbestlik } \\
\text { Derecesi }\end{array}$ & Kareler toplamı & $\begin{array}{l}\text { Kareler } \\
\text { Ortalaması }\end{array}$ & F Değ eri & $\begin{array}{l}\text { G+Ç+GÇ } \\
\text { KO Oranı(\%) }\end{array}$ \\
\hline Çeșitler & 5 & 36165 & 7233 & $1.60 ̈$ o & 6.29 \\
\hline Çevreler & 1 & 478601 & 478601 & $165.39^{* *}$ & 83.34 \\
\hline Tekerrür & 6 & 17362 & 2894 & 0.64 & - \\
\hline Çeșit x Çevre I nteraks. & 5 & 59446 & 11889 & $2.63^{*}$ & 10.35 \\
\hline PCAI I nteraksiyonu & 5 & 59446 & 11889 & $2.63^{* *}$ & - \\
\hline Hata & 30 & 135476 & 4516 & - & - \\
\hline Toplam & 47 & 727050 & 15469 & - & - \\
\hline DK(\%) & 10.48 & & & & \\
\hline
\end{tabular}

G:Genotip, Ç:Çevre, GÇi: Genotip Çevre Interaksiyonu, KO: Kareler Ortalaması,

**: 0.0I, *:0.05'e göre önemli, öd: önemli değil

Ana Etkiler ve çarpımsal interaksiyonlar (AMMI) analizine göre tane verimi bakımından çevreler arasında önemli farklılıkların olduğunu ve çevrenin diğer varyasyon kaynaklarına göre daha yüksek etkiye sahip olduğunu göstermiștir. Benzer sonuçlar bazı araștırııılar tarafından ortaya konulmuș ve kareler ortalamasında çevre etkisinin diğer iki varyasyon kaynağından daha yüksek olduğunu bildirmișlerdir (Bantayehu, 2013; Rezene, 2014; Doğan ve ark., 2016; Sayar, 2017; Pouresmael ve ark., 2018). Ayrıca Kendal ve Tekdal (2016), yaptıkları bir araștırmada arpada çevrenin genotip ve genotip çevre interaksiyonundan daha yüksek oranda tane verimi üzerinde etkili olduğunu bildirmișlerdir. Mehari ve ark. (2015) araștırma bulgularımızla uyumlu olarak ekmeklik buğdayda tane verimi özelliği bakımından kareler ortalamasında çevre etksinin \%78.3, genotip $x$ çevre interaksiyonun \% 4.6 , genotip etkisinin ise $\% 7.0$ olduğunu bildirmișleridir. Farshadfar ve ark. (2012), nın yapmıș olduğu bir çalșmada ekmeklik buğdayda tane verimi bakımından kareler ortalamasında çevre etksinin (\%59.39), interaksiyon biri çiçeklenme diğeri dane doldurma döneminde olmak üzere 2 defa sulama yapılmıștır. (14.34) ve genotiplerin (\%9.39) etkisinden daha yüksek olduğunu bildirmișlerdir. AMMI I modelinde, x-ekseni genotipleri ve çevrenin temel etkisini, $y$-ekseni ise interaksiyonu temsil etmektedir (Șekil I). Çevre ve genotipler hem temel etki hem de interaksiyon bakımından çok değișkenlik göstermișlerdir. Bu modele (AMMI I) göre; her iki çevrenin ortalama tane verimleri üzerinden yapılan değerlendirmede tescil adayı olan Sagitario çeșidi ile Cemre çeșidinin ortalama verimden daha düșük, diğer çeșitlerin ise ortalama verimden daha yüksek tane verimine sahip oldukları tespit edilmiștir (Șekil 3). Ayrıca Nurkent çeșidi TBElç̧

Temel Bileşen Analiz 1 Ortalama Sonucları

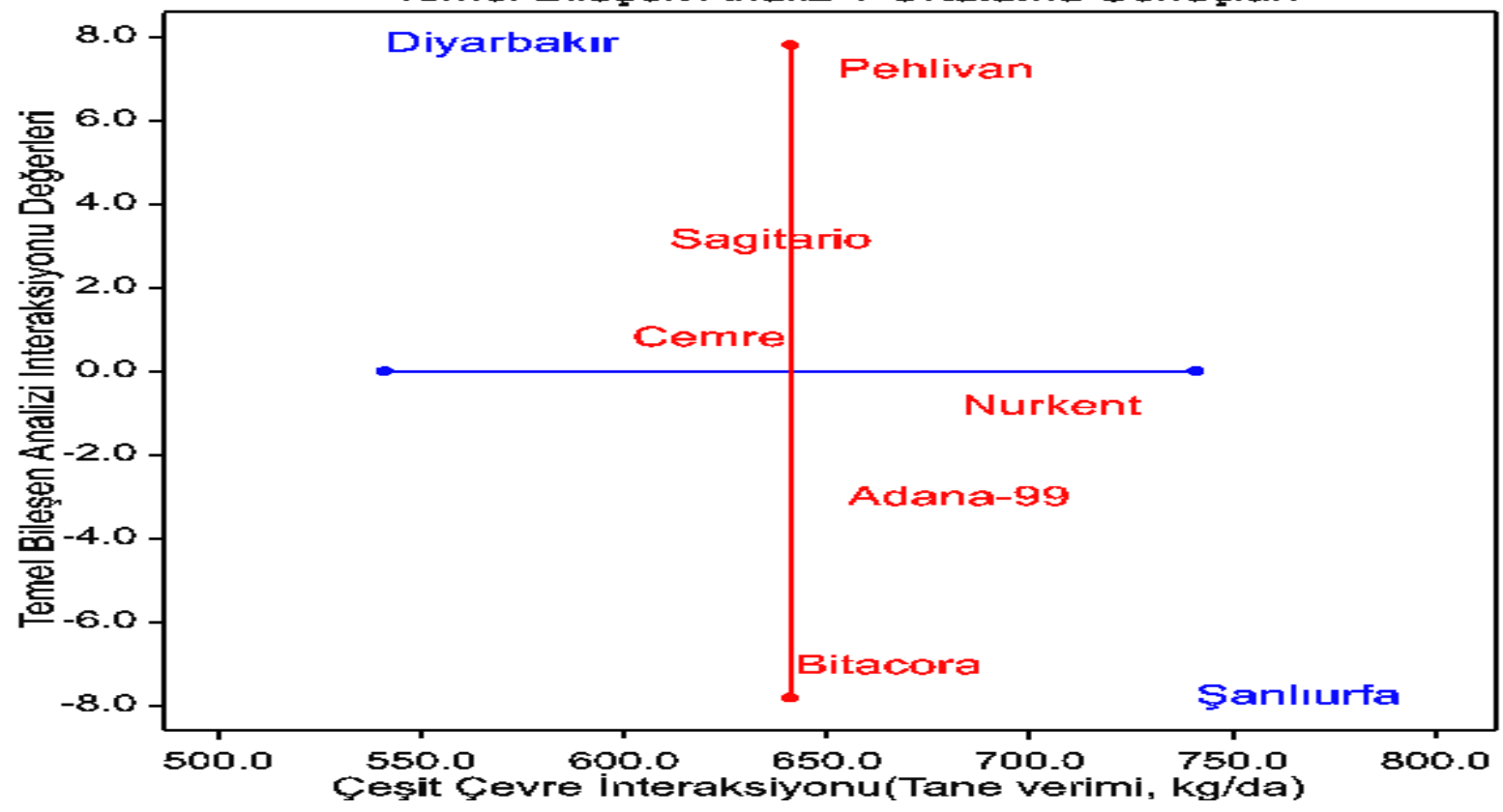

Șekil 3. AMMI I biplot grafiği iki çevrenin verim ortalamasına göre çeșitlerin stabilitesi 
(Temel Bileșen Ekseni interaksiyonu) (I) $b=0.75517$ değeri ile her iki çevrenin ortalama tane verimi bakımından stabilite çizgisine yakın olduğundan diğer çeșitlere göre daha stabil çeșit ve Pehlivan çeșidi $\left(\operatorname{TBE} \mathrm{I}_{c ̧}(\mathrm{I}) \mathrm{b}=-0.88592\right.$ değeri ile stabilite çizgisinden en
ORAL E, KENDAL E, DOĞAN Y uzak olduğundan dolayı stabilitesi zayıf olan çeșit oldukları tespit edilirken diğer çeșitler ise orta derecelerde stabiliteye sahip oldukları tespit edilmiștir (Çizelge 3).

Çizelge 3. Araștırmanın yürütüldüğü çevrelere ait tane verimi(kg/da) değerleri, olușan gruplar ve temel bileșen ekseni interaksiyonu çeșit, çevre skorları

\begin{tabular}{|c|c|c|c|c|}
\hline \multirow{2}{*}{ Çeșitler } & \multicolumn{2}{|l|}{ Çevreler } & \multirow{2}{*}{ Ortalama } & \multirow{2}{*}{ TBEI Çeșit Skoru(I) } \\
\hline & Diyarbakır & Șanlıurfa & & \\
\hline Adana-99 & 531.3 ef & $778.7 \mathrm{ac}$ & 655.0 & 3.05536 \\
\hline Cemre & $508.0 \mathrm{f}$ & 696.0 bd & 602.0 & $-7.0847 \mid$ \\
\hline Nurkent & 576.4 ef & $789.9 \mathrm{ab}$ & 683.2 & 0.75517 \\
\hline Pehlivan & $608.5 \mathrm{de}$ & $696.3 \mathrm{bd}$ & 652.5 & -0.88592 \\
\hline Sagittario & 535.4 ef & $686.7 \mathrm{~cd}$ & 611.1 & 7.1701 \\
\hline Bitarico & $486.7 \mathrm{f}$ & $797.0 \mathrm{a}$ & 645.2 & -0.823432 \\
\hline Ortalama & $54 I .1 \mathrm{~B}$ & $740.8 \mathrm{~A}$ & & \\
\hline TBEI Çevre skoru(I) & 7.80731 & -7.80731 & & \\
\hline
\end{tabular}

TBEl:Temel Bileșen Ekseni Interaksiyonu

Her iki çevrenin ortalama sonuçlarında; tane verimi bakımından Bitacora aday çeșidinin sadece Cemre ve Sagittario çeșitlerinden daha yüksek verim verdiği, stabilite değerleri bakımından ise sadece Pehlivan çeșidine göre daha stabil olduğu belirlenmiștir (Șekil 3). Diğer taraftan AMMI I modelin sonuçlarına göre Diyarbakır lokasyonunda verimin düșük (54l.l kg/da), Șanlıurfa lokasyonunda ise verimin oldukça yüksek (740.8 kg/da) olduğu görülmektedir (Șekil 3, Çizelge 4). Mirosavlievic ve ark. (20I4)'ına göre düșük TBEI । değerlerine sahip çeșitler daha stabil olduğu, Flores ve ark. (1998)'ına göre ise yüksek verime sahip genotipler dinamik stabiliteyi temsil etmekte ve ticari bitki ıslahında kullanılabileceği bildirilmektedir. Benzer sonuçlar; Kendal ve Tekdal (20l6 ), Kendal ve ark. (2016a)' nın yapmıș oldukları araștırma sonuçlarında da görmek mümkündür. AMMI I analizi sonuçlarına göre her çevre için sırasıyla önerilebilecek ilk dört çeșidin sıralaması Çizelge 4' te verilmiștir.

Çizelge 4. AMMI Analizine göre her çevre için sırasıyla seçilmesi gereken ilk dört çeșit

\begin{tabular}{lllllll}
\hline Çeșitler & $\begin{array}{l}\text { Ort. Verim } \\
(\mathrm{kg} / \mathrm{da})\end{array}$ & $\begin{array}{l}\text { Çevrelerin } \\
\text { Skorları }\end{array}$ & I.Çeșit & 2.Çeșit & 3.Çeșit & 4.Çeșit \\
\hline Diyarbakır & $54 I .1$ & 7.807 & Pehlivan & Nurkent & Sagitario & Adana-99 \\
Șanlıurfa & 740.8 & -7.807 & Bitacora & Nurkent & Adana-99 & Pehlivan \\
\hline
\end{tabular}

TBElç[I]:I. Çeșidin Temel Bileșen Ekseni İnteraksiyonu

Bu analiz sonucunda Diyarbakır lokasyonunda ilk sırada tercih edilmesi gereken çeșit Pehlivan, Șanlıurfa lokasyonunda tescil adayı Bitacora çeșidi, her iki çevrede de ikinci sırada ise Pehlivan çeșidinin tercih edilmesi gerektiği söylenebilir. Ayrıca Adana 99 çeșidi Șanlıurfa'da Sagittario çeșidi ise Diyarbakır'da 3. sırada seçilmesi veya bașvurulması gereken çeșitlerdir (Çizelge 4). Kendal ve Doğan (20I5) ile Kendal ve ark. (20I6a) çalıșma bulgularımızla uyumlu olarak, birden fazla çevreye en uygun ilk iki sıradaki çeșidi veya çeșit adaylarını tüm çevredeki durumlarını görmek açısından AMMI analizi son derece önemli sonuçları aktarma özelliğine sahip olduğunu bildirmișlerdir. Șekil 2' AMMI 2 biplot modeli ise ilk iki Temel Bileșen Ékseni İnteraksiyonu (TBEI) ile ilgili modelleri görsel olarak çok iyi açıklama fırsatını vermektedir (Șekil 4).

AMMI 2 analiz modeli tarafından gösterilen genotip çevre interaksiyonu, özellikle interaksiyonun iki temel bileșen eksen arasında bölündüğünde etkisi ortaya çıkmaktadır (Çizelge 3). Bu model birçok araștırıcı tarafından değerlendirilmiștir (Gauch ve Zobel 1996; Yan ve Hunt 200I; Kendal ve ark., 2016; Kendal ve Tekdal 2016). AMMI analizinin bu modeli genotip çevre etkileșimini iki yönlü hesaplamaktadır. Hata kareler ortalamasının sonuçlarına göre, TBE I (temel bileșen ekseni) ve TBE 2 eksenlerinin interaksiyonu \%।.0' e göre önemli bulunmuștur. Ayrıca AMMI 2 analiz sonuçları TBE I ekseninin kareler ortalamasının \%62.35'ine, TBE 2 nin ise \%37.65'sine sahip olduğu, toplamda ise her iki bileșenin kareler ortalamasının \% 100'ünü olușturduğu tespit edilmiștir (Șekil 4, 5, 6 ve 7). Akçura ve ark. (20I I), çok özel veya geniș adaptasyona sahip üstün ekmeklik buğday genotiplerin seçimi, ilk iki GGE biplot bileșeninin (PCAI ve PCA2) genotipik ve çevresel skorları kullanılarak üretilen bir biplot ile belirlendiğini bildirmișlerdir. Șekil 4, genotip çevre interaksiyonun ilk iki eksenine ait değerleri yüzdelik olarak açıklamaktadır (Vargas ve Crossa, 2000; Sayar ve Han, 2015). AMMI 2 ekseni farklı hassasiyete sahip genotipleri çevresel değișkenliklere karșı genotip çevre interaksiyonunu olușturabilmektedir. Ayrıca AMMI 2 açık bir șekilde hangi genotipin hangi çevreye daha uygun olduğunu göstermekte ve genotiplerin çevrelere olan uyumluluk oranlarını ortaya çıkarmaktadır (Kendal ve Sayar, 2016). Șekil 2' ye göre çeșitler biplot üzerinde farklı noktalarda yer aldıklarından dolayı genetik olarak oldukça farklı olduklarını göstermekle birlikte Cemre ile 


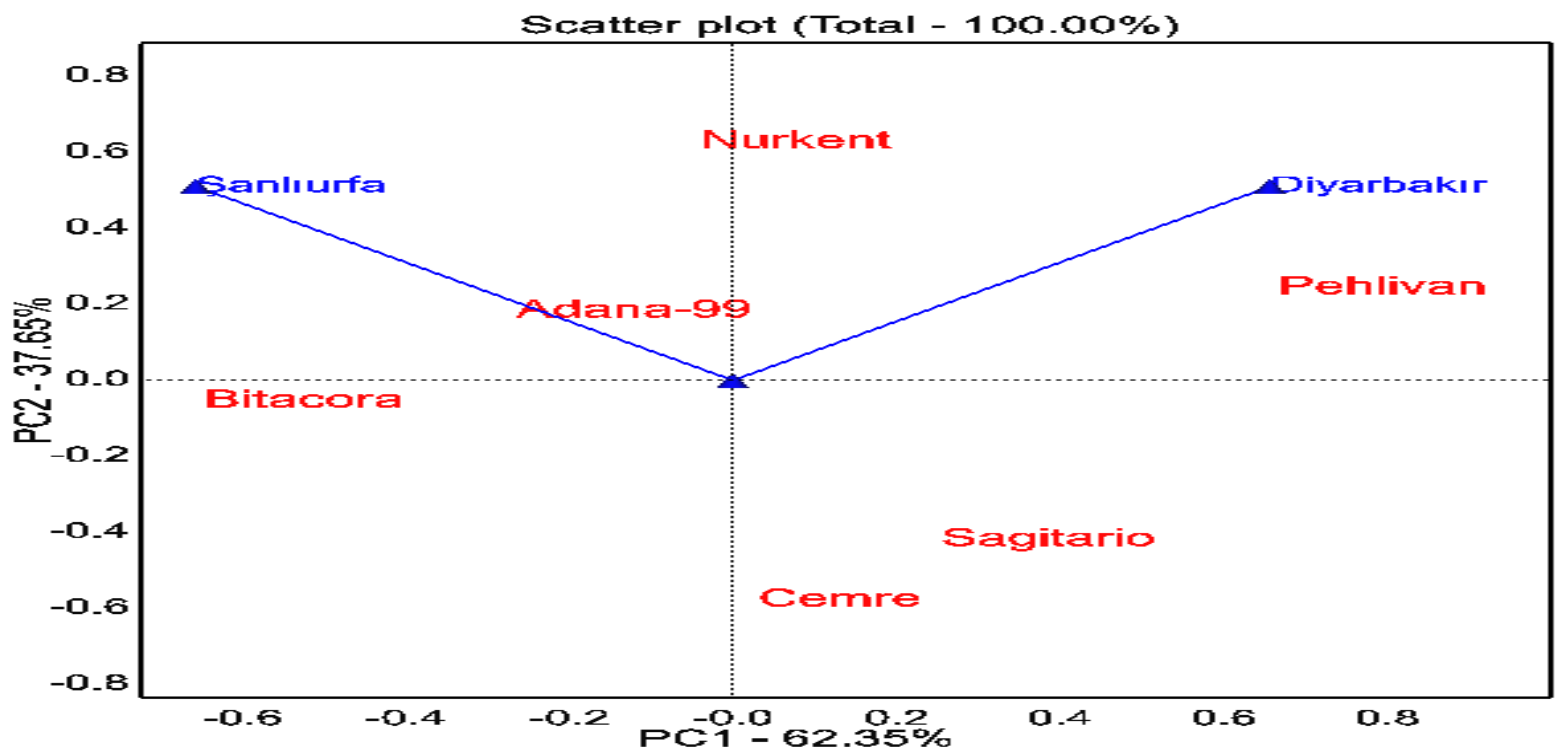

Șekil 4. Tane verimi bakımından genotip çevre interaksiyonunu gösteren AMMI 2 biplot grafiği

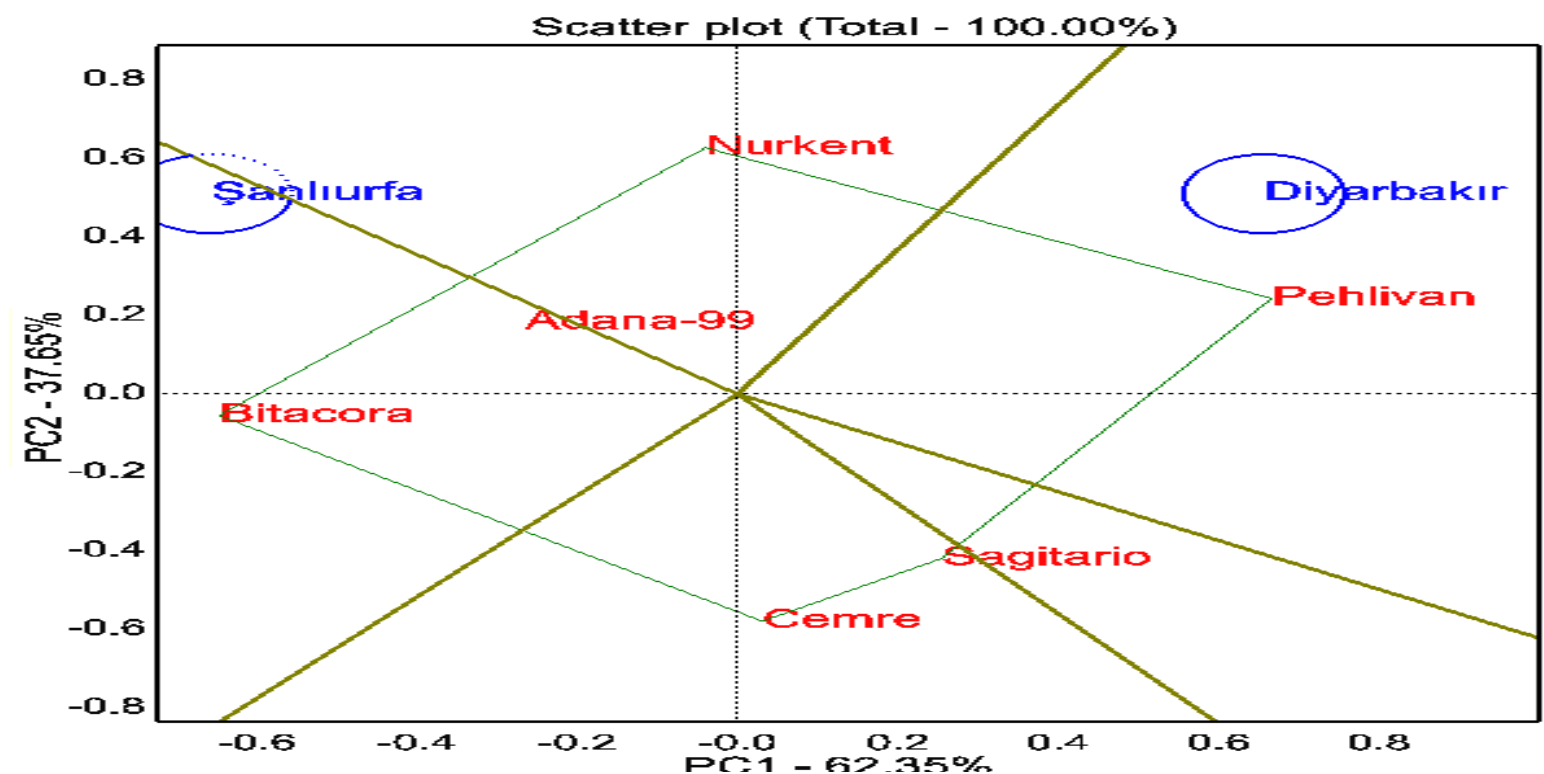

Șekil 5. Tane verimi bakımından beș çeșidin iki çevre üzerinden sektôr ve gruplandırmasını gösteren scatter biplot grafiği Sagittario çeșitlerinin kendi aralarında genetik olarak daha yakın olduğunu göstermektedir. Biplot üzerinde Pehlivan çeșidinin Diyarbakır lokasyonuna, çeșit adayı Bitacora' nın ise Șanlıurfa lokasyonuna daha yakın olduğu dolayısıyla bu lokasyonlar için uygun çeșitler olduğu söylenebilir. Ayrıca Biplot grafiği üzerinde lokasyonların konumlandığı yerlerin merkezinde yer alan Nurkent çeșidi diğerlerine göre daha iyi uyum gösterdiğini söyleyebiliriz. Benzer bir araștırmada genotiplerin stabilitesi ile ilgili, GGE biplotun AMMI ile karșılaștırıldığında daha yararlı ve etkili olduğu farklı çevrelerde uygun genotipleri belirlemek için daha uygun bir model olduğu belirtilmiștir (Aktaș, 2016).

AMMI 2 poligonu çoklu çevre şartlarından elde edilen tane verimi bakımından genotipleri birbiriyle ve çevrelerle ilișkilendirmekte ve hangi genotipin hangi çevreye daha uyumlu olduğunu göstermektedir (Șekil 5). Ayrıca çevreleri de farklı sektörlere ayırarak gruplandırmaktadır. Islam ve ark. (2014)' nın yapmıș olduğu bir çalıșmada genotip ve çevreler aynı sektör içinde yer alıyorsa bu iki faktörün etkileșimi pozitif, farklı sektörlerde yer alıyorsa negatif bir etkileșim, tümü aynı 


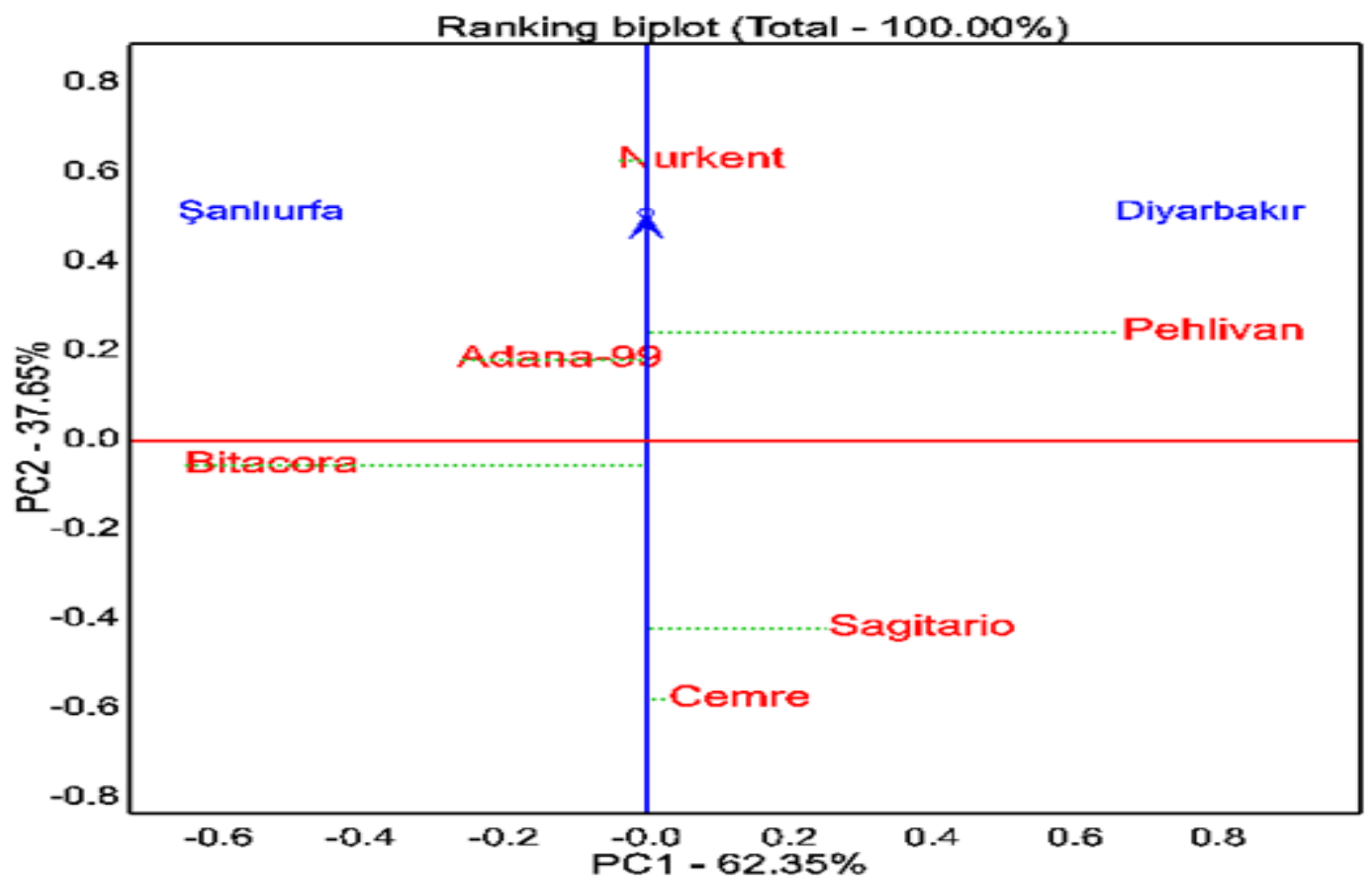

Șekil 6. Tane verimi bakımından çeșitlerin ortalama verimlerini ve çevrelere göre stabilitesini gösteren ranking biplot grafiği

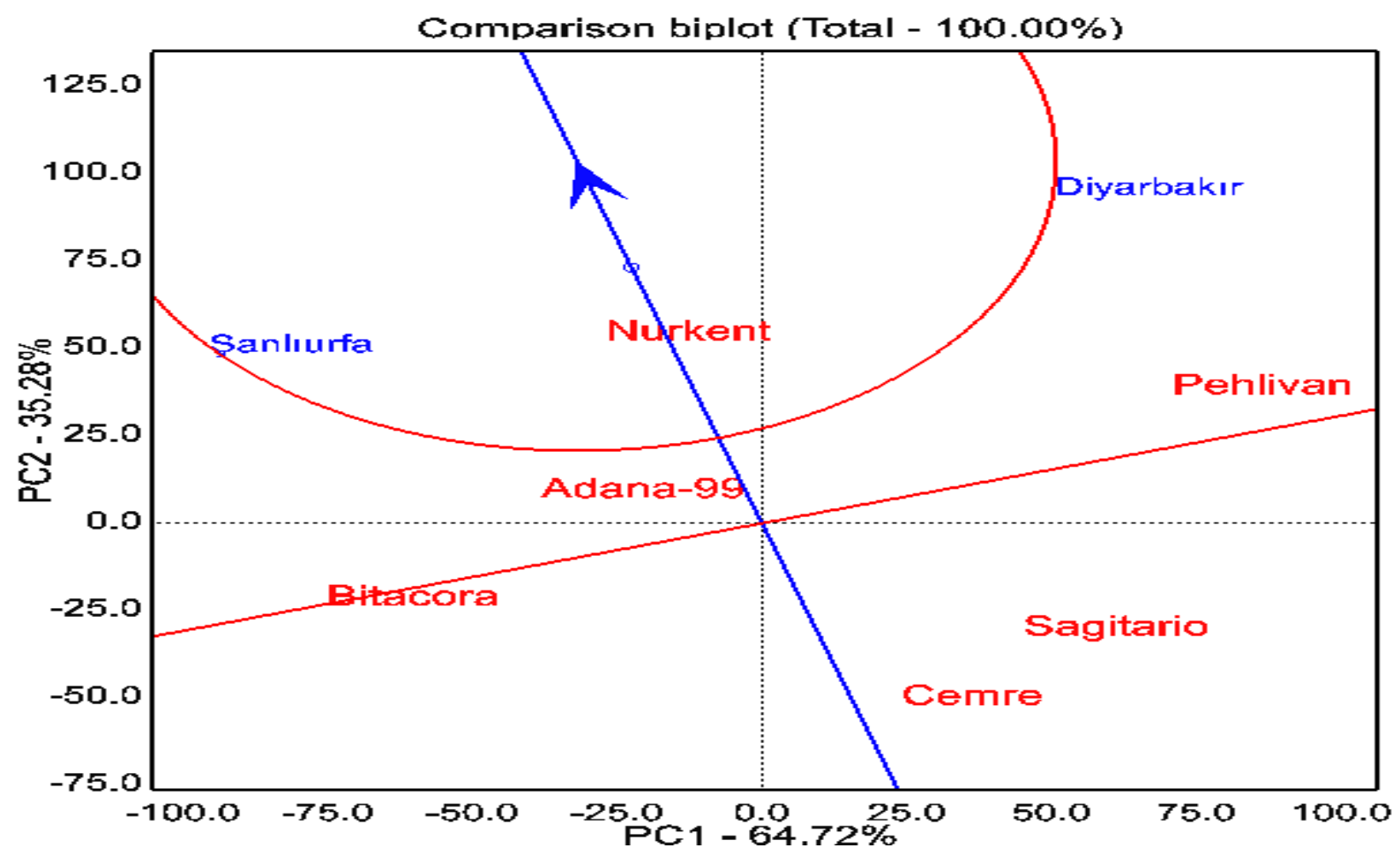

Șekil 7. Tane verimi bakımından çeșitlerin çevrelerin ideal çevreye göre sıralanması ve çeșitlerin ideal çevreye göre uyumunu gösteren comparison biplot grafiği 
bildirmișlerdir. Ayrıca Akter ve ark., (20/4), genotipler șekil üzerinde birbirlerine çok yakın görünüyorlarsa tüm çevrelerde birbirlerine yakın, genotipler aksi yönde yer alıyorsa o zaman genotipler birbirinden çok farklı verim sektörde yer alıyorsa karıșık bir etkileșim olduğunu sonuçlarına sahip olduğunu bildirmektedir. Șekil 5' e göre, aday çeșidin mevcut çeșitlerle kıyaslandığı bu çalıșmada çevreler temel olarak beș sektör'e ayrılmıștır. Diyarbakır lokasyonu ile birlikte Pehlivan çeșidi 2. sektör; Șanlıurfa lokasyonu ile birlikte çeșit adayı Bitacora ve Adana 99 çeșitleri 5. Sektörde yer almıștır. Nurkent çeșidi tek bașına 2 . ve 5 . sektör arasında bulunan 4 . sektörde yer alarak her iki lokasyon için uygun olduğu diğer çeșitler ise lokasyonlardan bağımsız sektörlerde yer alarak uyum kabiliyetlerinin daha zayıf olduğu tespit edilmiștir. Aynı yılda yürütülen çevrelerin farklı sektörlerde yer alması çevrelerin birbirlerinden farklılıklarını göstermektedir. Bu çalıșmada çeșit adayı olarak kullanılan Bitacora poligon üzerinde Șanlıurfa lokasyonuna daha yakın olması bu lokasyonda çalıșmada kullanılan standartlara göre daha iyi uyum gösterdiğini söylemek mümkündür. Yapılacak buğday adaptasyon çalıșmalarında her sektörden birer çevrenin seçilmesi ve çevreleri artırmak için daha farklı yerlerin seçilmesi çeșitlerin stabilitesi üzerinde daha etkili sonuçların alınması muhtemeldir. Çalıșmada kullanılan çeșitlerin farklı sektörlerde yer alması verim bakımından bu genotiplerin genetik olarak farklı olduğunu, Cemre ve Sagittario çeșitlerinin ise tane verimi bakımından genetik olarak birbirine daha yakın olduğu tespit edilmiștir. Benzer sonuçlar Kendal ve ark. (2016)'nın yapmıș olduğu biplot çalıșmasında da elde edilmiștir. Sabaghnia ve ark. (20l0), çokgen olarak görülen sektör biplot grafiği tamamen olmasa da genellikle orijinal verilere dayanmaktadır. Ayrıca Gauch (1988), bu model çıktıların amaçlarını tavsiye etmek için çok uygun olduğunu bildirmiștir. Biplot görsel olarak çok çevreli verim denemelerinde (MEYT) belirli bir bölgede çeșitli mega ortamlarının varlığını değerlendirmek için önemli olduğunu bildirmiștir (Ubaidi ve ark., 2013). Ranking biplot yöntemi, her iki lokasyonun tane verimi ortalaması üzerinden çeșitlerin stabilitesi ve her iki çevre için de en uygun çeșidi tanımlamak için bize fikir vermektedir (Șekil 6). Ranking biplot șekline (Șekil 6) göre, Nurkent, Adana 99 ve Pehlivan çeșitleri ortalama verim çizgisinin üzerinde diğer çeșitler ise ortalama verim çizgisinin altında kaldığı, Nurkent çeșidi ok ile belirtilen stabilite çizgisinin merkezinde yer aldığı dolayısıyla stabil olduğu, özellikle Bitacora çeșit adayı ise ok ile gösterilen stabilite çizgisinden oldukça uzak olduğu görülmektedir. Bu șekil üzerinden yapılacak çeșit uyum değerlendirmesinde; her iki lokasyon için öncelikli olarak Nurkent çeșidinin tercih edilmesinin gerekliliğini ve çeșit adayının (Bitacora) ise diğer çeșitlere göre stabilite çizgisine daha uzak, ancak Cemre ve Sagittario çeșitlerine göre daha yüksek ortalama verime sahip olması ikinci dereceden tercih edilmesinin daha doğru olacağını göstermektedir. Bazı araștırmacılar, yaptıkları biplot çalıșmalarında Biplot Ranking modelinin görsel karșılaștırmayı kolaylaștırmak ve bitki yetiștiriciliğinde genotiplerin stabilite ve
ORAL E, KENDAL E, DOĞAN D adaptasyon yeteneğine göre daha pratik önerilerde bulunmak için uygun bir model olduğunu bildirmișlerdir (Ahmadi ve ark., 2012; Kendal ve ark., 2016).

Comparison biplot modeli ise her iki lokasyonun ortalama tane verim değerleri üzerinden temsili olarak ideal bölgeyi (ok ile belirtilen) belirleyip ve bu ideal bölgeye göre araștırma konusu olan çeșitleri sıralamaktadır (Șekil 7). Kaya (2006), araștırmasında yüksek ortalama verim performansını sergileyen ve stabil olan genotipler ideal genotipler olarak tanımlamıștır. Șekil 7' ye göre ok ile belirtilen ve daire ile sınırları belirlenen ideal bölgenin içerisinde yer alan Nurkent çeșidi her iki lokasyon ortalamasında tane verimi bakımından görsel olarak öncelikli tercih edilmesi gereken ideal çeșit olduğunu göstermektedir.

Adana 99 ve Pehlivan çeșitleri ise ortalama verim çizgisinin üzerinde yer aldıkları ve en ideal bölgeye yakın konumlandıklarından dolayı, ikinci dereceden tercih edilmesi gereken çeșitler olduğu görülmektedir. Diğer çeșitler ve aday çeșit (Bitacora) görsel olarak hem ortalama verim çizgisinin altında kaldıklarından dolayı hem de ideal bölgeden oldukça uzakta yer aldıklarından dolayı bu lokasyonlardaki uyum sonuçlarına göre birinci ve ikinci derecede tercih edilmemesi gereken çeșitlerdir. Comparison biplot modeli ortalama veriler üzerinden araștırma konusu olan çeșitleri temsili ideal çeșide göre sıraladığından dolayı seleksiyonda ve adaptasyon çalıșmalarında görsel olarak bize daha iyi seçme fırsatı sunduğu için kullanılması gereken bir model olduğu görülmektedir. Benzer sonuçlar GGE Biplotun bu modelini kullanan çeșitli araștırıcılar tarafından da ifade edilmiștir (Jalata, 20II; Karimizade ark.., 20I3; Kendal ve Sayar, 2016)

\section{SONUC}

$\mathrm{Bu}$ araștırmanın sonuçları Biplot ve AMMI analiz modelleri ile değerlendirilmiș ve aday çeșidin adaptasyon kabiliyeti ve stabilite yeteneği mevcut çeșitlerle kıyaslanmıștır.

Ayrıca çalıșmanın yürütüldüğü Șanlıurfa lokasyonunun yüksek verim $(740.8 \mathrm{~kg} / \mathrm{da})$ Diyarbakır lokasyonunun düșük verim $(54 \mathrm{l} . \mathrm{l} \mathrm{kg} / \mathrm{da})$ potansiyeli çevre șartlarına sahip olduğu anlașılmıștır. Araștırma sonuçlarına göre, mevcut iki çeșitten daha yüksek diğer üç çeșitten daha düșük verime sahip Bitacora çeșidi, Șanlıurfa lokasyonunda ilk sırada tercih edilmesi gereken çeșit olduğu tespit edilmiștir. Ekmeklik buğday açısından tane verimi kadar önemli olan kalite kriterleri açısından da iyi sonuçlara sahip olduğu takdirde, bu aday çeșidin araștirmanin yürütüldüğü bölgelerde yetiștiriciliğinin tavsiye edilebileceği sonucuna varılmıștır. Ayrıca AMMI ve Biplot analiz modelleri ile görsel olarak çeșitlerin stabilite durumları incelenebileceği gibi çeșitler özel ve genel adaptasyon yeteneklerine göre çevrelere tavsiye edilebileceği sonucuna varılmıștır.

\section{KAYNAKLAR}

Ahmadi J, Mohammadi A, NajafiMirak T (20I2) Targeting promising bread wheat (Triticum aestivum L.) lines for cold climate growing environments using AMMI and SREG GGE Biplot Analyses. Journal Agriculture Science Technic 14: 645- 657 . 
Akçura M, Taner S, Kaya Y (20II) Evaluation of bread wheat genotypes under irrigated multi-environment conditions using GGE biplot analyses. Žemdirbystè Agriculture 98: 35-40.

Aktaș H (2016) Tracing highly adapted stable yielding bread wheat (Triticum aestivum L.) genotypes for greatly variable south-eastern Turkey. Applied Ecology and Environmental Research I4:I59-I76.

Akter A., Hassan M.J, Kulsum MU, Islam MR, Hossain K, Rahman MM, (2014) AMMI biplot analysis for stability of grain yield in hybridrice (Oryza sativa L.). J. Rice Resarch 2: 126.

Anonim (2012) https://www.mgm.gov.tr (Erișim tarihi: $0 \mathrm{l} / 0 \mathrm{l} / 20 \mathrm{I3}$ ).

Bantayehu M, Esmael J, Awoke Y (2013) Additive main effect and multiplicative interaction analysis and clustering of environments and genotypes in malting barley. African Journal of Agricultural Research 8 : 1896-1904.

Carbonell SA, Filho JA, Dias LA, Garcia AA, Morais L (2004) Common bean genotypes and lines interactions with environments. Sci. Agric., (Piracicaba Braz.) 61: 169-177.

Doğan Y, Kendal E, Oral E (20I6) Identifying of relationship between traits and grain yield in spring Barley by GGE biplot analysis. The Journal "Agricultural and Forestry" 62 : 239-252.

Farshadfar E, Poursiahbidi M, Mandjasemi M (2012) Evaluation of phenotypic stability in bread wheat genotypes using GGE-biplot. International Journal of Agriculture and Crop Sciences 4: 904-910.

Flores F, Moreno MT, Cubero JI (1998) A comparison of univariate and multivariate methods to analysis environments. Field Crops Resarch 56: 27I-286.

Gauch HG, Zobel RW (1996) AMMI analyses of yield trails. Genotype by environment interaction. GRC. Paton, Florida 4: 85-122.

Gauch HG (1988) Model selection and validation for yield trials with interaction. Biometrics 44: 705-7I5.

Islam MR, Anisuzzaman M, Khatun H, Sharma N, Islam Z, Akter A, Parta S, Biswas (2014) AMMI Analysis of yield performance and stability of rice genotypes across different haorareas. Ecology Friendly Agriculture Journal 7: 20-24.

Jalata Z (20II) GGE-biplot Analysis of Multienvironment yield trials of barley (Hordeum vulgare L.) genotypes in Southeastern Ethiopia Highlands. International Journal of Plant Breeding and Genetics 5: 59-75.

Karimizadeh RM, Mohammadi M, Sabaghni N, Mahmoodi AA, Roustami B, Seyyedi F, Akbari F (20I3) GGE biplot analysis of yield stability in multi-environment trials of lentil genotypes under rainfed condition. Notulae Scientia Biologicae, 5:256-262.

Kaya Y, Akçura M, Taner S (2006) GGE-Biplot analysis of multi-environment yield trials in bread wheat. Turk Journal Agriulture Forestry 30: 325-337.

Kendal E, Doğan Y (2015) Stability of a candidate and cultivars (Hordeum vulgare L.) by GGE Biplot
ORAL E, KENDAL E, DOĞAN D analysis of multi-environment yield trials in spring barley. Agriculture and Forestry 61: 307-318.

Kendal E, Sayar MS (2016) The stability of some spring Triticale genotypes using Biplot Analysis. The Journal of Animal \& Plant Sciences, 26: 754-765.

Kendal E, Șener O (2015) Examination of genotype environment interactions by GGE biplot analysis in spring durum wheat. India Journal of Genetic and Plant Breeding 75: 34l-348.

Kendal E, Tekdal S (2016) Application of AMMI model for evolution spring barley genotypes in MultiEnvironment trials- Bangladesh Journal Botany 45: 613-620.

Kendal E (20I3) Bazı makarnalık buğday çeșitlerinde genotip $x$ çevre interaksiyonunun kalite ve verim özellikleri üzerine etkisi. MKÜ, Fen Bilimleri Enstitüsü, Tarla Bitkileri Ana bilim dalı, Kasım 2013, (Doktora Tezi), Hatay.

Kendal E, Doğan Y, Oral E (2016a) Ana etkiler ve çarpımsal İnteraksiyonlar AMMI analizi ile çoklu çevre șartları üzerinden yazlık arpa çeșit adayının mevcut çeșitlerle karșılaștırılması. I. Uluslararası Akdeniz Bilim ve Mühendislik Kongresi, 26-28 Ekim 2016. Çukurova Üniversitesi, Adana/Türkiye, 320I-3209.

Kendal E, Sayar MS, Tekdal S, Aktaș H Karaman M (2016b) Assessment of the impact of ecological factors on yield and quality parameters in triticale using GGE biplot and AMMI Analysis. Pakistan Journal Botany 48: 1903-1913.

Kendal E, Tekdal S, Aktaș H, Karaman M (20I2) bazı makarnalık buğday çeșitlerinin diyarbakır ve adıyaman sulu koșullarında verim ve kalite parametreleri yönünden karșılaștırılması. Uludağ Üniversitesi Ziraat Fakültesi Dergisi 26: I-I4.

Kılıç H (2014) Additive main effect and multiplicative interactions (AMMI) Analysis of grain yield in barley genotypes across environments. Journal Agricultural Science 20: 337-344.

Kılıç H, Akçura M, Uçar R, Aktaș H, Kökten K, Tekdal S (2016)Yerel ekmeklik buğday popülasyonundan seçilmiș saf hatlarda bazı özellikler arası ilișkilerin belirlenmesi. Tr. Doğa ve Fen Derg._Tr. J. Nature Science, 5:12-16.

Kılıç H, Aktaș H, Kendal E, Tekdal S (2012) İleri kademe ekmeklik buğday (Triticum aestium L.) hatlarının biplot analiz yöntemi ile değerlendirilmesi. Bingöl Üniversitesi, Fen Bilimleri Enstitüsü. Türk Doğa ve Fen Dergisi I: I32-139.

Kılıç H, Erdemci İ, Karahan T, Karahan, H Aktaș, Kendal E (2005) Güneydoğu Anadolu Bölgesi șartlarında bazı ekmeklik buğday çeșitlerinin uyum kabiliyetlerinin tespit edilmesi. Harran Üniversitesi Ziraat Fakültesi, GAP IV. Tarım Kongresi I: 809-8I4.

Kılıç H, Kendal E, Aktaș H, Tekdal S (20I4) ileri kademe ekmeklik buğday hatlarının farklı çevrelerde tane verimi ve bazı kalite özellikleri yönünden değerlendirilmesi. Iğdır Üniversitesi Fen Bilimleri Enstitüsü Dergisi 4: 87-95. 
Kılıç H, Tekdal S, Kendal E, Aktaș H (2012) Augmented deneme desenine dayalı ileri kademe makarnalık buğday (Triticum turgidum ssp durum) hatlarının biplot analiz yöntemi ile değerlendirilmesi. KSÜ Doğa Bilimleri Dergisi I5: 12-25.

Mehari M, Tesfay M, Yirga $H$, Mesele A, Abebe T, Workineh A, Amare B (20I5) GGE biplot analysis of genotype-by-environment interaction and grain yield stability of bread wheat genotypes in South Tigray, Ethiopia. Communications in Biometry and Crop Science 10: 17-26.

Mirosavlievic MN, Przulj N, BocanskiStanisavlievic D, Mitrovic B (2014) The application of AMMI model for barley cultivars evaluation in multi-year trials. Genetika 46: 445-454.

Pouresmael M, Kanouni H, Hajihasani M, Astraki $H$, Mirakhorli A, Nasrollahi M, Mozaffari J (2018). Stability of chickpea (Cicer arietinum L.) landraces in national plant gene bank of Iran for drylands. Journal of Agricultural Science and Technology 20: 387-400.

RadNouri MR, Abdulkadir M, Rafii MY, Hawa ZEJ, Naghavi MR, Ahmadi F (20I3) Genotype environment interaction by $A M M I$ and GGE biplot analysis in three consecutive generations of wheat (Triticum aestivum L) under normal and drought stress conditions. Australian Journal Crop Science 7: 956-96I.

Rezene Y (2014) GGE and AMMI biplot analysis for field pea yield stability in SNNPR state Ethiopia. Internat. Journal Sustainable Agrilculture Resarch I: 28-38.

Sabaghnia N, Dehghani H, Alizadeh B, Mohghaddam M (2010) Genetic analysis of oil yield, seed yield, and
ORAL E, KENDAL E, DOĞAN D yield components in rapeseed using additive main effect and multiplicative interaction Biplots Agronomy Journal 102: 136I-1368.

Sayar MS, Han Y (20I5) Determination of seed yield and yield components of grasspea (Lathyrus sativus L.) lines and evaluations using GGE biplot analysis method. Tarım Bilimleri Dergisi- Journal Agriculture Science 21: 78-92.

Sayar MS, Anlarsal AE, Bașbağ M (2016) Macar Fiğ (Vicia pannonica Crantz.) genotiplerinde biyolojik verim özelliği bakımından çevreler üzerinden eklemeli ana etkiler ve çarpımsal interaksiyonlar (AMMI) analizi. Tarla Bitkileri Merkez Araștırma Enstitüsü Dergisi 25 (Özel sayı-2):235-240.

Sayar MS. (2017) Additive main effects and multiplicative interactions (AMMI) analysis for fresh forage yield in common vetch (Vicia sativa L.) genotypes. Agriculture and Forestry 63: 119-127.

Ubaidi MOA, Al-kaisy AM, Al-issawi MH, Fadhel F, Fuller $M$ (20I3) Performance assessment of wheat cultivars under three locations using GGE-biplot. Journal of Genetic and Environmental Resources Conservation I: 262-270.

Vargas M, Crossa J (2000) The AMMI analysis and the graph of the Biplot in SAS. Centrolnternacional de Mejaromiento de Maizy Trigo (CIMMYT). Mexico, 42.

Yan W, Hunt LA (200I) Interpretation of genotype $x$ environment interaction for winter wheat yield in Ontario. Crop Science 4I: 19-25. 